\title{
Głos z Litwy. \\ O teatrze Oskarasa Koršunovasa
}

DOI: http://dx.doi.org/10.12775/LC.2018.016

\begin{abstract}
Streszczenie: Artykuł analizuje trzy spektakle Oskarasa Koršunovasa zrealizowane z jego własnym zespołem OKT: Hamleta (2008), Na dnie (2010) i Mirandę (2011). Realizacje klasycznych dramatów prezentują szereg reżyserskich rozwiązań - zarówno poszczególnych scen, jak i całych wątków świadczących o oryginalnej interpretacji, wywiedzionej z własnych przeżyć bądź doświadczeń litewskiego społeczeństwa. Pozostają jednak zaskakująco lojalne wobec problemów, jakie poruszali klasyczni autorzy. Koršunovas należy - obok Ostermeiera, Warlikowskiego czy Jarzyny - do pokolenia reżyserów, którzy po 1989 roku walczyli o nowy język teatralnej wypowiedzi. Litwin okazał się także odporny na mody i ideologie nowego świata. To artysta świadomie nawiązujący do dramatycznej historii, ale i do rudymentów europejskiej cywilizacji.
\end{abstract}

Słowa kluczowe: teatr litewski, teatr pożerający życie prywatne, alkoholizm, dysydent, zarażenie złem, metafizyczna pustka

\section{The voice from Lithuania. Oskaras Koršunovas theatre}

\begin{abstract}
The article analyses three productions directed by Oskaras Koršunovas, produced in his own group OKT: Hamlet (2008), At the bottom (2010) and Miranda (2011). These productions of classical dramas present a series of directorial solutions - both individual scenes and entire themes - which signal original interpretations derived from his own experiences or the experiences of Lithuanian society. However, they remain surprisingly loyal to the problems posed by the classical

\footnotetext{
* Teatrolożka, recenzentka teatralna, członkini redakcji „Teatru”, selekcjonerka i jurorka festiwali teatralnych, autorka recenzji, szkiców i artykułów naukowych o współczesnym teatrze europejskim.

E-mail: kalina.zalewska@wp.pl.
} 
authors. Koršunovas belongs - alongside Ostermeier, Warlikowski and Jarzyna - to the generation of directors who after 1989 fought for a new language of theatrical expression. He has also proved himself to be resistant to the fashions and ideologies of the new world. He is an artist consciously referring to dramatic history, but also to the rudiments of European civilization.

Keywords: Lithuanian theatre, theatre devouring private life, alcoholism, dissident, infection by evil, metaphysical emptiness

o publikacji szkicu Łukasza Drewniaka Mus. Opowieść o Oskarasie Koršunovasie i jego generacji (Drewniak 2013a), pisanie o tym reżyserze i jego sztuce wydaje się karkołomne. Autor bowiem doskonale pokazal, z czego wynika i na czym polega tworzony przez Koršunovasa teatr, jacy byli i są ludzie, których wokół siebie gromadził, wreszcie kim jest ten artysta dla swojego pokolenia i litewskiego teatru. Wilnianin, jako nastolatek zachwycony spektaklami Nekrošiusa, potem uczeń mistrza Jonasa Vaitkusa, debiutował w wieku niespełna dwudziestu jeden lat, po zaledwie trzech semestrach studiów, objawiając wielki talent i na zawsze przepadając w teatralnym labiryncie. Trzon jego zespołu tworzą dziś niemal ci sami co przed laty artyści, współdecydujący o randze jego sztuki.

Litewski teatr - odkąd pojawił się w Polsce dzięki takim festiwalom, jak toruński „Kontakt”, wrocławski „Dialog” i gdański Festiwal Szekspirowski - ekscytował odmiennością i wysoką jakością. Wyznaczały ją osiągnięcia Jonasa Vaitkusa (ur. 1944), Eimuntasa Nekrošiusa (ur. 1952), Rimasa Tuminasa (ur. 1952) i młodszego od nich prawie o pokolenie Oskarasa Koršunovasa (ur. 1969). Był on tym reżyserem, który wprowadzał do litewskiego teatru nowy język, najpierw wystawiając oberiutów (debiut: Tam być tu według Daniiła Charmsa i Aleksandra Wwiedenskiego, 1990; Starucha według Charmsa, 1992 i Starucha 2, 1994), potem nowych brutalistów, w końcu zwracając uwagę na Szekspira i klasykę (warto wspomnieć zwłaszcza o Śnie nocy letniej, 1999, Romeo i Julii, 2003 oraz Mistrzu i Małgorzacie Bułhakowa, 2000). Stał w jednym szeregu z Thomasem Ostermeierem, Grzegorzem Jarzyną i Krzysztofem Warlikowskim. Z Jarzyną łączy go zainteresowanie niemiecką dramaturgią: Ogień w głowie (2000) i Pasożyty (2001) Mariusa von Mayenburga były jednymi z pierwszych utworów, które zrealizował Litwin, kiedy w 1998 roku założył własny teatr - Oskaro Koršunovo Teatras (OKT); Uroczystość Mogensa Rukova i Thomasa Vinterberga (2001) stała się manifestem i wielkim sukcesem Jarzyny, niedługo po objęciu dyrekcji Rozmaitości. Upodobanie do tych samych dramatów łączy Koršunovasa z Warlikowskim. Obaj w pewnym momencie sięgnęli po Roberta Zucco Bernarda-Marie Koltèsa (Warlikowski w 1995, Koršunovas w 1998 roku), a potem, co ważniejsze, po Hamleta i Burzę; dla obydwu Szekspir stał się rodzajem wyzwania, poprzez jego sztuki opowiadali świat. Choć ich interpretacje okazały się bardzo od siebie odległe.

Przyjrzyjmy się trzem przedstawieniom dojrzałego już reżysera - szczególnie ważnym i osobistym wypowiedziom. Koršunovas prowadzi w nich kilka tematów jednocześnie, co powoduje, że są bogate w znaczenia i wymykają się jednoznacznym interpretacjom. Być może uda się oświetlić je z innej strony, niż pokazał to Drewniak. 


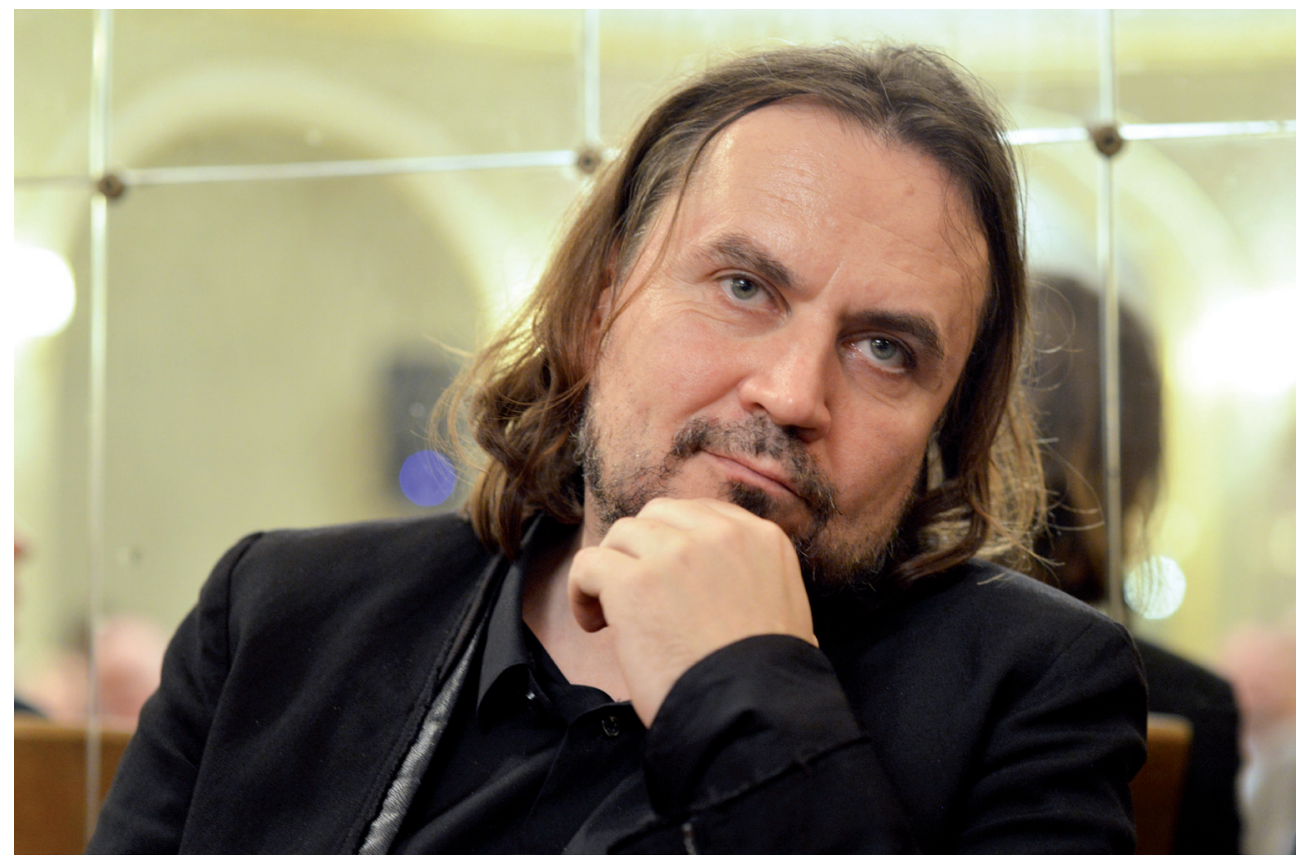

Oskaras Koršunovas

Fot. Wojtek Szabelski.

$\mathrm{Z}$ archiwum Teatru

im. W. Horzycy

\section{Pułapka na ludzi}

Hamlet (2008) trzydziestodziewięcioletniego Koršunovasa był dojrzałą i niezwykle osobistą wypowiedzią: powstał po kilkunastu latach niezwykle intensywnej pracy w teatrze, a reżyser przyznawał się w nim, bodaj po raz pierwszy, do alkoholizmu. Hamleta grał jego rówieśnik Darius Meškauskas: siwiejący młodzieniec o zmęczonej twarzy. Podczas spektaklu pociągał od czasu do czasu z butelki, zwracając potem „efekty” pijaństwa do kubła. Pił Johnniego Walkera.

Naczelne pytanie spektaklu „Kim jesteś? Ktoś ty?”, było zadawane widzom już w pierwszej scenie - tak brzmi pierwszy wers dramatu (Drewniak 2013a). Aktorzy, siedząc przed rzędem luster, tyłem do widowni, wykrzykiwali te pytania do samych siebie, a zarazem do publiczności, która oglądała ich odbicia. Kilkuminutowa sekwencja kończyła się nagłym zwrotem do widzów. Jej ekspresja sprawiała, że wybrzmiewały donośnie. W telewizyjnym wywiadzie reżyser tak rozwijał ich treść i zakres: „Kim jesteś? Może nikim? Czy masz być nikim? Jak rozumiesz siebie i swoje miejsce na świecie? Po co żyjesz? Czy zemsta jest koniecznością, czy też to czyn bezsensowny? I kto tak naprawdę się mści?”. I dodawał: „Dla teatru te poszukiwania są teraz najważniejsze” (Matuszak 2008).

Hamlet Koršunovasa operował trzema kolorami: czarnym, białym i czerwonym. Teatralne toaletki jeżdżące na kółkach miały białe blaty i szuflady, a nad lustrem światło jarzeniówki. Aktorzy przesuwali je, z nich właśnie budując scenografię i oświetlenie do każdej ze scen. Grały w nich lustra, światło, biel i teatralność sprzętów. Kostiumy były czarne, tak jak wystrój sceny, tylko Ofelia występowała w prostej, białej sukni z atłasu, którą praso- 
wał Poloniusz, a w domu ojca w błękitno-zielonym szlafroku, z pobieloną twarzą. Istotnym kolorem był czerwony. W drugiej części spektaklu płachty bibuły w tym kolorze spadały, pokrywając scenę. Hamlet po zabójstwie Poloniusza rzucał w twarz Klaudiusza czerwone oblepiające tworzywo, a ten wściekły z równą siłą przerzucał je na twarz Gertrudy. Reżyser dążył do metafory, operując poetyckim językiem.

Sceny były od siebie oddzielone wyciemnieniami, co tworzyło klamrę i rytm całości, przypominając filmowy montaż. W spektaklu znalazło się wiele sytuacji prywatnych, kiedy patrząc na odbicie w lustrze, aktorzy zmywali lub nakładali makijaż, powtarzali tekst albo palili papierosa jak grająca Gertrudę Nelè Savičenko, ubrana w czarną, atłasową koszulkę na ramiączkach i kozaki na wysokim obcasie. Koršunovas grał prywatnością aktorów i reżysera, pokazując, że stanowi ona część składową teatru: jego siłę i zarazem słabość. Wybrzmiewały bowiem dwa tematy: kończąca pewną epokę tragedia duńskiego księcia i jego otoczenia, bohaterów spalających się na ołtarzu historii, a zarazem tragedia reżysera i grających w spektaklu aktorów spalających się na ołtarzu sztuki.

W jednej z pierwszych scen było widać, jak Hamlet Meškauskasa w samotności pomstuje i płacze nad śmiercią ojca i własną matką, leżąc na toaletkach. Nie dając sobie rady z problemami, popija, ukrywając butelkę, gdy wchodzą Gertruda z Klaudiuszem. W trakcie dramatycznej rozmowy z matką, krzycząc, przeskakiwał nad skuloną Gertrudą, co było dobitnym wyrazem atmosfery spotkania i tego, co się w jego trakcie działo (natarcie syna miało zachwiać postępowaniem matki). Kiedy książę odkrywał podsłuchujących, Poloniusz (Vaidotas Martinaitis) padał na podłogę, za nim (inaczej niż u autora) stał Klaudiusz. Koršunovas rozgrywał scenę w obecności sprawcy intrygi, unaoczniając jej ukryty sens; za wszelką cenę unikał konwencji realistycznej. Kiedy pokazywał zaaranżowaną przez dwór rozmowę Hamleta i Ofelii, w której odsłaniali oni prawdę o sobie i łączącym ich uczuciu dawał im na to czas (scena była rozgrywana w białych kwiatach, za którymi ukrywali się podsłuchujący; były one motywem pojawiającym się wraz z postacią bohaterki). Ofelia Rasy Samuolytè tuliła do siebie rozpaczającego Hamleta, a pocałunek był zaskoczeniem dla obojga (kontrastowało to ze związkiem Gertrudy i Klaudiusza, który miał erotyczny charakter: w jednej ze scen oglądaliśmy przez chwilę twarze i ręce aktorów wychylające się zza luster w nagłym spazmie). Rozpoczynając monolog „Być albo nie być”, bohater odwracał się tyłem i długo patrzył na siedzący w głębi sceny, wydobyty światłem, upozowany dwór, w tym własną narzeczoną.

Dainius Gavenonis grał Klaudiusza, a zarazem starego Hamleta. Po pierwszej sekwencji to on ustawiał toaletki znów przodem do widzów, z powrotem meblując scenę, ustanawiając swój porządek. Długi czarny płaszcz, a pod nim nagi tors były kostiumem nowego króla. Kiedy aktor grał Ducha, zostawał tylko w czarnych spodniach. Przerażonemu Hamletowi ukazywał się nagle trup ojca, leżący na blatach toaletek, oświetlony jarzeniówkami i odbijający się w lustrach. Nagi tors nieruchomego ojca był pierwszym spotkaniem z jego śmiercią. Ale kiedy Hamlet podchodził blisko, wykonując gest czułości, ten chwytał go za gardło, wyraźnie się z nim mocując. $Z$ trudem powracał z zaświatów na rozmowę z synem. Ożywał, by opowiedzieć o morderstwie, demonstrując na Hamlecie, jak wlano mu do ucha truciznę. Jak przerwano jego życie nagle, nie dając czasu na pożegnanie i rozliczenie. Ten sam gest powtarzał potem syn podczas przedstawienia granego w Elsynorze.

Scena ta, podobnie jak scenografia Koršunovasa, stanowiła klucz do spektaklu. Aktorów Zabójstwa Gonzagi grali bowiem odtwórcy głównych bohaterów. Specjalnie dla 
tej sceny bielili twarze, zakładali czarne peleryny i białe kryzy. Grali jednocześnie i jednych, i drugich: występujących aktorów i reagujących na ich grę protagonistów. Ich grą, niczym capocomico, dowodził Hamlet, tak naprawdę była to jego opowieść. W tej scenie najwyraźniej widać, że Koršunovas utożsamiał się z bohaterem, czyniąc go reżyserem.

Rosencrantz (Tomas Žaibus) i Guildenstern (Giedrius Savickas) wkraczali na scenę w sukienkach i ciemnych okularach, kręcąc damskimi torebkami, ale z zarostem i w męskim obuwiu. Hamlet, kiedy już zupełnie nie miał złudzeń co do ich intencji, kazał jednemu z nich zagrać na flecie, trzymanym na wysokości rozporka. Koršunovas cytował tu rozwiązanie Warlikowskiego, odbierane u nas jako obyczajowy eksces i komentowane w recenzjach. Ale jego bohaterzy nie bulwersowali, pozostając na marginesie spektaklu. W Warszawie kobiety grające zakochanych gejów i łącząca je relacja były eksponowane i naprawdę niepokoiły. Temat wchodził też na pierwszy plan, bo niepewna była seksualna tożsamość Hamleta. Tymczasem spektakl Koršunovasa celował w nieuczciwe reguły gry na szczytach władzy i we własnej rodzinie, ale jednocześnie w teatr angażujący bez reszty, wyciągający z artystów życiowe siły. Był w związku z tym bardzo teatralny i formalny, choć zarazem niezwykle dramatyczny, co chyba najlepiej widać w finale pozbawionym klasycznych scen walki.

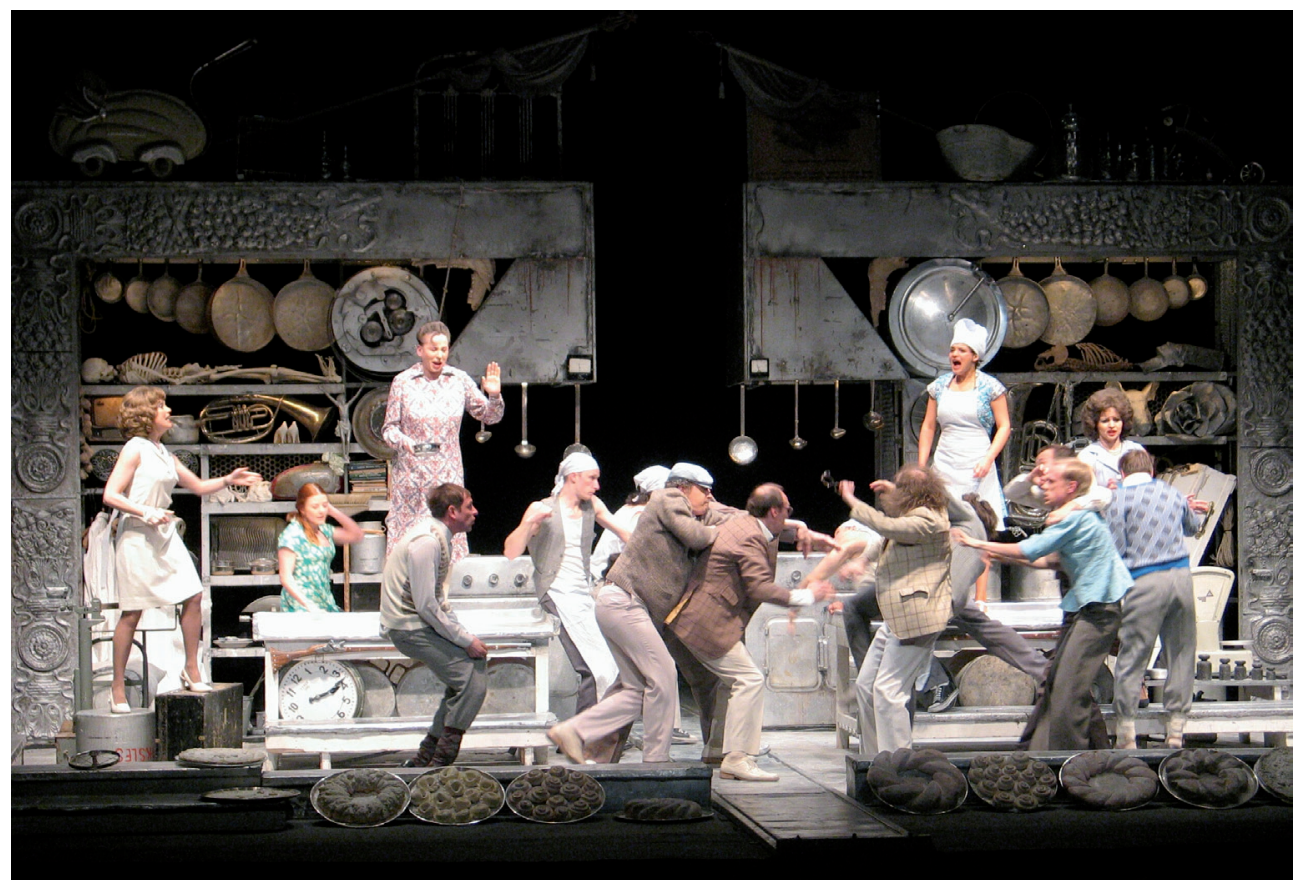

Scena zbiorowa z Romea i Julii W. Szekspira w reż. Oskarasa Koršunovasa Fot. Wojtek Szabelski. Z archiwum Teatru im. W. Horzycy

Zastąpiła je krótka konfrontacja z Laertesem (Darius Gumauskas) na słowa i ciosy, podczas której on i Hamlet czerwienieli od rozmazanej na twarzach i torsach farby. Gertruda żegnała się z życiem, trzymając w ręku zamiast zatrutego kielicha czaszkę Yoricka. Savičenko, wstając z miejsca przy swojej toaletce, patrzyła na syna, a potem na pierwszego męża. Klaudiusza w ogóle nie było. Reżyser kończył wątki inaczej niż Szekspir, pomijając uzurpatora, rozgrywając wszystko w gronie właściwej rodziny. Stary i młody Hamlet padali 
sobie w ramiona, co powodowało, że twarz ojca stawała się czerwona od krwi, którą spływał syn. Hamlet jeszcze raz powracał do „Być albo nie być”, tym razem nerwowo wykrzykując je światu, co przypominało ekspresję pierwszej sceny przedstawienia. Rozlegał się wojskowy marsz, pojawiający się nagle Fortynbras zamaszystym ruchem wyłączał światła przy kolejnych toaletkach, przed którymi siedzieli aktorzy. W końcu były widoczne tylko - wydobyte punktowo - twarze obu Hamletów, starego i młodego. Fortynbras noszący wojenny makijaż, a na nosie jak klaun czerwoną kulkę na gumce, zamykał powieki bohatera (postać klauna pojawiała się wcześniej, czerwoną kulką bawił się Julius Žalakevičius grający Horacego i Fortynbrasa).

W spektaklu co jakiś czas było słychać pisk myszy grasujących po Elsynorze, jedna z nich przeniknęła do spektaklu, pojawiając się między bohaterami, grana przez jednego $\mathrm{z}$ aktorów. Ponieważ reżyser pokazywał nad poziomem luster oświetlone głowy lub dłonie bohaterów, czasami można było zobaczyć tam także łeb monstrualnej myszy. Czy Koršunovas znał podanie o Popielu, a zwierzęta asystujące bohaterom tragedii czekały po prostu na swój posiłek? Czy też białe myszy były rojeniem pijącego Hamleta, z czasem potężniejącym i coraz bardziej wyraźnym (Zembrzuski)? Może jednak obie interpretacje da się pogodzić, skoro grane są tu dwa tematy: na finał zmagań bohaterów szekspirowskiej tragedii czekały piszczące z głodu myszy; na reżysera i aktorów, spalających się na ołtarzu sztuki - widoczne znaki delirium.

Warlikowski w swoim Hamlecie (1999) rozwinął niektóre pomysły Konrada Swinarskiego, który jako pierwszy dostrzegł kompleks Edypa i seksualne niezdecydowanie bohatera, a także homoseksualizm Rosencrantza i Guildensterna (Zawrzykraj 2000). Inspirował się też eseistyką Jana Kotta, u progu naszego wieku twierdzącego, że współcześnie najbardziej interesująca u Szekspira wydaje się ambiwalencja płci (Kott 1999). Przede wszystkim jednak odkrył kluczowy temat własnej twórczości. Koršunovas czytał tych samych autorów i, podobnie jak Warlikowski, odnajdywał swój życiowy temat, ale jego interpretacja rozwinęła się w zupełnie innym kierunku. „Co robi Hamlet? On przerywa niekończący się ciąg zemsty, zamyka w ten sposób pewną epokę” (Koršunovas 2011) - mówił po polskiej premierze Mirandy. Była to teza Kotta, który przytaczał ją za Jeanem Parisem (Kott 1997). Porządek tak mocno obecny w kronikach królewskich Szekspira, nazwany przez Kotta Wielkim Mechanizmem, zgodnie z którym walkę o władzę rozpoczynała seria mordów, a kończyła koronacja, a po jakimś czasie po koronę sięgał potomek zgładzonych i wszystko się powtarzało - zostaje w Hamlecie przezwyciężony. Fortynbras, który, zgodnie z tą regułą, musiałby zemścić się na Hamlecie, skoro stary Hamlet zabił starego Fortynbrasa - wkracza do Elsynoru, gdzie żyje już tylko Horacy. Zarządza więc pochówek ofiar, a nawet nazywa Hamleta bohaterem.

Ciekawa jest jednak uwaga reżysera, każąca pomyśleć o bohaterze Szekspira jako o kimś, kto, być może pod wpływem nauk w Wittenberdze, choć na wpół świadomie, ociąga się z morderstwem Klaudiusza i w rezultacie sam pada ofiarą: raz odstąpiwszy zdrajcy, nie znajduje w sobie motywacji do mordu, o czym zresztą mówi, spotykając żołnierzy Fortynbrasa, pozbawionych tych wątpliwości (scena obecna w wileńskiej inscenizacji). Imperatyw czynu i zemsty zdaje się słabnąć, choć bohater obwinia się z tego powodu. Hamlet jest już człowiekiem nowej epoki, przeczuwającym absurd Wielkiego Mechanizmu.

Koršunovas przekonując z kolei, że wybaczenie, na które zdobywa się Prospero w Burzy, jest najważniejsze, powoływał się na ojca bohatera: „Przypomnijmy sobie: stary Hamlet 
mówi przecież, że został zamordowany w samym rozkwicie swoich grzechów. I właśnie to jest najstraszniejsze" (Koršunovas 2011). Z krótkich komentarzy rzucanych przy okazji mówienia o innym spektaklu - świadczących o tym, jak silnie Hamlet tkwi w głowie reżysera i jak istotna była to dla niego wypowiedź - wynika, że Koršunovas czyta Szekspira z Kottem w jednej, ale z Biblią w drugiej ręce (do której, jak sam wielokrotnie podkreślał, stale powraca), zachowując w swoich spektaklach pamięć o chrześcijańskim porządku. Może dlatego, mimo nowego języka, którym porozumiewa się z dzisiejszą widownią, w jego spektaklu zostały ocalone obrazy, które współczesna kultura odrzuca: niewinność obojga młodych; ból starego Hamleta spowodowany nagłą śmiercią przecinającą możliwość rozliczenia i pożegnania się z życiem; strach młodego Hamleta przed zgładzeniem Klaudiusza, kiedy ten się modli, by nie postawić go w sytuacji lepszej, niż znalazł się ojciec.

Warlikowski, w przeciwieństwie do Litwina, nie uwzględnia tej perspektywy. Jego Hamlet stawia na pierwszym miejscu kwestię tożsamości seksualnej. Bohater interesuje się przede wszystkim własną odmiennością, co wydaje się zrozumiałe, bo zmienia ona każdą relację z Innym. Jest przyzwoitym człowiekiem, który reaguje na niesprawiedliwość i przemoc. Jednak podstawowe role społeczne (syna, męża, ojca) pełni w inny sposób niż większość z nas. Podczas gdy u Koršunovasa Hamlet jest heteroseksualnym mężczyzną, który identyfikuje się z ojcem i kocha Ofelię. Ma tylko problem z alkoholem. Dramaty obu bohaterów i ich sytuacje egzystencjalne są zupełnie inne i prowadzą do różnych rozwiązań.

\section{Ostatnia wieczerza}

Alkoholizm, ale i metafizyczna pustka stały się tematem powstałego dwa lata później $\mathrm{Na}$ dnie (2010) na motywach dramatu Maksyma Gorkiego. Kameralny spektakl został rozegrany na małej scenie wileńskiego teatru, za długim stołem, w konwencji biesiady (u nas był prezentowany na Scenie na Zapleczu toruńskiego teatru). Zakładał interakcję z publicznością, wciągając ją do gry, by zdemaskować obyczaj przyzwolenia na picie i szczególnej tolerancji wobec niego.

Scenariusz Koršunovasa przenosił akcję dramatu we współczesne realia. Opierał się na sytuacji z ostatniego aktu rozgrywającego się w przytułku dla bezdomnych, już po śmierci Anny i zabójstwie Kostylewa, co tłumaczyło nieobecność na scenie osób wmieszanych w morderstwo, oraz starca Łuki, syberyjskiego zesłańca bez paszportu, który pojawia się u Gorkiego w pierwszym akcie i znika zaraz po zabójstwie. Łuka, portretowany przez autora jako jedyny sprawiedliwy, który dla jednych staje się autorytetem, dla drugich przeciwnie, zdecydowanie dzieli społeczność. Jest w dramacie figurą świętego starca, zgodnie z rosyjską tradycją traktowanego jako znak obecności Boga w świecie. Bohaterowie po krótkim obcowaniu z nim zostają sami i muszą sobie z tym nagłym odejściem poradzić.

Koršunovas przez wybór i kompozycję tekstu unieważnił niejako intrygę dramatu, a wydobył jego sensy egzystencjalne. Pokazał rozterki, jakie wzbudziła postać „starego", czyniąc spektakl rodzajem rozprawy z nieobecnym, a zarazem swoistego pożegnania. Obraz sceniczny - w widoczny, ale nie dosłowny sposób - nawiązywał do Ostatniej wieczerzy Leonarda da Vinci. Aktorzy siedzieli za stołem, przeróżnie pogrupowani, w toku akcji zmieniając miejsca, ale blisko środka zawsze zasiadał pełniący rolę przywódcy Satin wraz 
z towarzyszącym mu Baronem. Satin jednak, wbrew pozorom, nie był figurą Chrystusa. Jeśli pozostać przy ewangelicznych skojarzeniach, był on raczej figurą Piotra, który miał ukoić ból po stracie mistrza, czyli odejściu Łuki, i poprowadzić zdezorientowanych. Baron zaś pozostawał wobec niego w opozycji. W przeciwieństwie do idealistów zarażonych wpływem „starego”, uważał go za szarlatana, który niepotrzebnie zawrócił im w głowach. Jeżeli były więc w spektaklu nawiązania do słynnego fresku i Ewangelii, to do sytuacji po odejściu Nauczyciela i opuszczonych apostołów.

Ale ostatnia wieczerza Koršunovasa była przede wszystkim rodzajem libacji. Reżyser uczynił tematem spektaklu kiepską kondycję dzisiejszego świata, pozostającą w zastanawiającym kontraście do cywilizacyjnych osiągnięć, i alkoholizm bohaterów. Satin rozpoczynał go niemal prywatnym stwierdzeniem, podsumowującym bezowocne próby ulepszenia ludzkiej natury w ostatnim stuleciu. Płynnie przechodził do tekstu Gorkiego, ale nie pamiętał już trudniejszych określeń, nie miał też wiary w ich znaczenie i moc. Ani wykształcenie, które wspominał, ani talent, o którym opowiadał Aktor, nie okazały się decydujące. Siedzący za stołem patrzyli widzom w oczy i zdawali się pytać, czy może oni odnaleźli sens. Przed nimi stały chipsy i woda mineralna, którą popijali. Nagle jednak ktoś wyciągał spod stołu napoczętą butelkę wódki. Sytuacja ulegała wyraźnemu rozluźnieniu. Aktorzy już całkiem otwarcie proponowali widzom, że się z nimi napiją. Szli „w publiczność” z butelkami i kieliszkami. Skracali dystans, bratali się, wchodzili w rozmowy, Rasa Samuolytė flirtowała z jednym z widzów. Ci ochoczo przystawali na to, jeszcze raz potwierdzając, że ten nawyk działa nadal mimo zmian ustrojów i granic. Okazuje się najbardziej trwałym dziedzictwem naszej części Europy, a może całej Europy, której mapa wisiała na ścianie podczas spektaklu. Po jakimś kwadransie aktorzy zasiadali z powrotem za stołem, stawiali na nim alkohol i rozpoczynali dalszą część swojej historii. Wiedzieli już, że ich świetnie zrozumiemy.

Rezygnując z nieco zwietrzałej intrygi Gorkiego, reżyser ocalił jego postaci; odrzucając realistyczny kostium sprzed wieku, skupił się na istocie ludzkich relacji. Wydobył w ten sposób to, czego inaczej może byśmy nie zauważyli. Rozmowy o „starym”, prawdzie i życiu pokazywały potrzebę sensu i tęsknotę za wyższym porządkiem, skontrastowaną z nieustannym, przypisanym naszej naturze wątpieniem. Ich klimat był nacechowany wyraźną ironią wobec bezskuteczności ludzkich wysiłków pozbawionych zakorzenienia. Reżyser zwracał też uwagę na rolę alkoholu w życiu bohaterów, którzy właśnie dlatego znaleźli się na dnie. Nie z racji społecznych różnic, biedy czy politycznej opresji, ale egzystencjalnych kłopotów, które usiłowali w ten sposób leczyć. Alkohol połączył różnych bohaterów: lepszych i gorszych, głupszych i mądrzejszych, wyżej i niżej urodzonych, z talentem i bez talentu. Prezentowali oni obecną egzystencję jako rodzaj życia po życiu, kiedy wspomina się to dawne z całą świadomością, że nie ma już do niego powrotu.

W podstawowej dla spektaklu relacji Satina i Barona widać, że obaj piją na umór, choć z różnych powodów. Widać też, że jaki taki ład mogą wcielać natury silniejsze, zaś podważanie sensu jest cechą słabszych. Charakterny Satin (znakomity Dainius Gavenonis) jest co prawda szulerem i mordercą, ale dobrze czuje, że świat musi trzymać się zasad, a „stary” miał rację, budząc tęsknotę za dobrem i dając nadzieję. Baron natomiast (równie świetny Darius Meškauskas), który zgrzeszył tylko w ten sposób, że zmarnował własne życie, nieustannie rozsiewa zwątpienie, podkopując fundamenty, na których wznosi się i tak krucha równowaga otoczenia. Celuje zwłaszcza w idealizm Nastii, ale także w nadzieje Aktora wierzącego, że zwalczy swój nałóg. 
W sytuację czwartego aktu wpisano niektóre dialogi z poprzednich, np. opowieść Nastii z aktu trzeciego, która płynnie przechodzi w jej spór z Baronem, zapisany w akcie czwartym. Prowadzi on do ostrego starcia, zakończonego rozbiciem rzuconego z impetem talerza, w czym objawia się urażona duma i dzika wściekłość młodej kobiety. Jest to triumf Samuolytė, przeprowadzającej postać Nastii od idealistycznych marzeń o miłości, przez kpiny i szyderstwa ze scenicznego partnera, do jego zanegowania. Meškauskas z kolei wzrusza, kiedy opowiada o arystokratycznej rodzinie Barona, z trudem wydobywając z pamięci początek tej historii i niejako dziwiąc się sobie, z uporem dokonującemu złych wyborów i systematycznie marnującemu własne szanse.

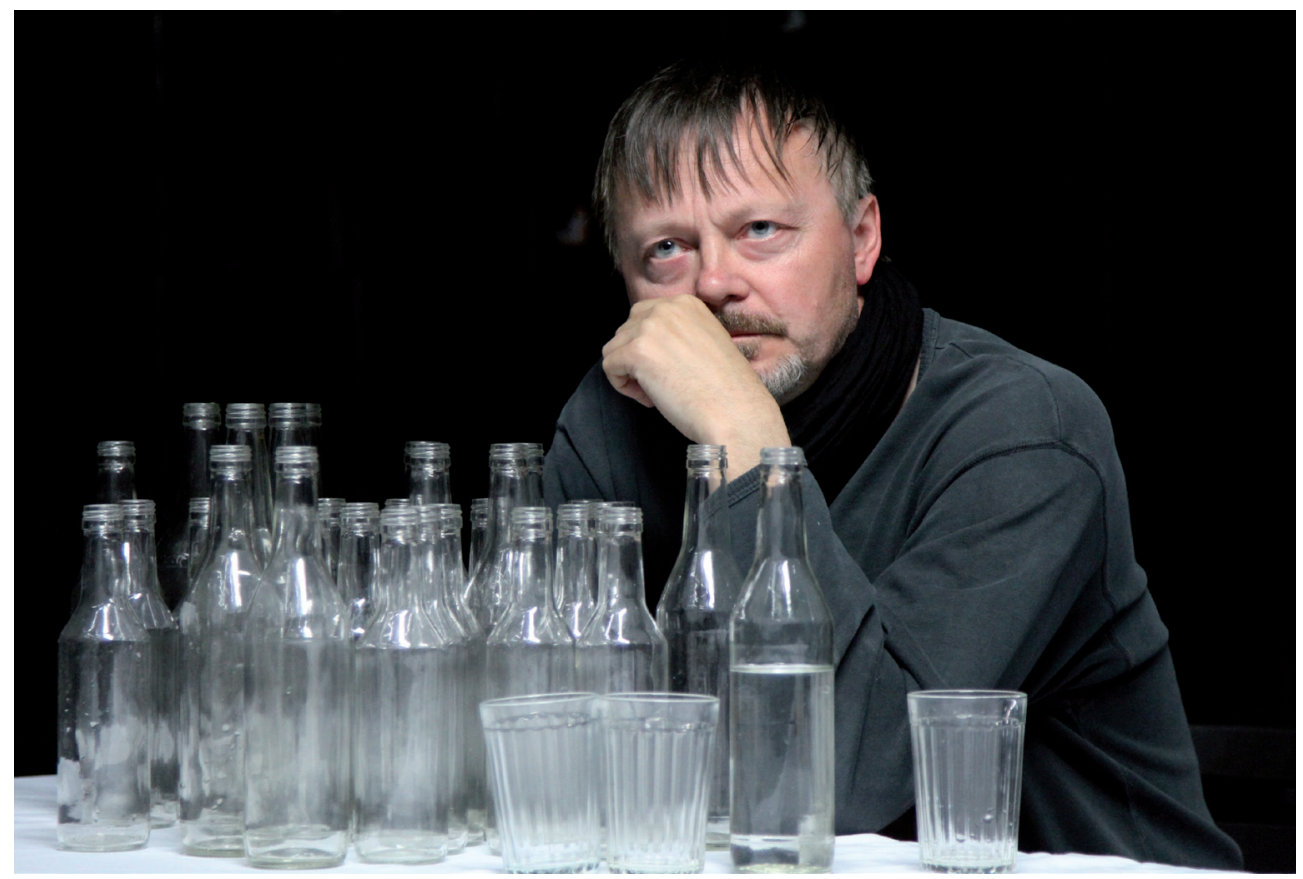

Darius Meškauskas w Na dnie M. Gorkiego w reż. Oskarasa Koršunovasa

Fot. Magdalena Kujawa

Po ciśnięciu w ścianę talerza klimat spektaklu znowu ulegał zmianie. Aktorzy wyciągali dziesiątki opróżnionych już butelek i z zapamiętaniem ustawiali je na stole. Upływ czasu był więc mierzony ubytkiem alkoholu. Ironia tego intermedium gryzła w oczy, a atmosfera wyraźnie tężała. Nadchodził czas na dramatyczne wyznanie Aktora i ludyczną część imprezy w postaci wtargnięcia Bubnowa (Julius Žalakevičius), Miedwiediewa (Rytis Saladžius), Kwaszni (Nelè Savičenko) i Aloszki (Giedrius Savickas), podczas której ten pierwszy opowiada, jak to o mało co nie zabił żony; Kwasznia o tym, jak często mężczyźni biją swoje kobiety, a Aloszka wykonuje rosyjski taniec z przysiadami.

Niezwykle ważnym bohaterem okazywał się Aktor (Darius Gumauskas). Koršunovas portretował w tej postaci artystę, który wierzył we własny talent, ale przegrał z nałogiem. Początkowo ufa jeszcze, że uda mu się pokonać słabość, bierze aktywny udział w sporach. Potem wydaje się coraz bardziej nieobecny, przesuwając się tylko między bohaterami. Wysiłki Aktora, który chce zadeklamować Tatarowi (Tomas Žaibus) swój popisowy mo- 
nolog, ale nie może przypomnieć sobie ani jednego słowa, to najbardziej dramatyczne sekwencje spektaklu... Reżyser kończył go samobójstwem Aktora, którym Gorki zwieńczył swój dramat, dając mu jednak szansę na wymarzoną wypowiedź. Był to monolog Hamleta po spotkaniu z aktorami, kończący drugi akt tragedii Szekspira („Och, jakież ze mnie podłe, tępe bydlę!”), przechodzący w „Być albo nie być”. Pochwała sztuki, ale też brak woli działania, o które oskarża się Hamlet, są portretem - z jednej strony niesłychanych możliwości, jakie otwierają się przed ludźmi, z drugiej: destrukcyjnej skłonności do ich marnotrawstwa. Finałowy monolog zwraca też uwagę, że oba spektakle pozostają w dialogu. Obsada Hamleta niemal pokrywa się z obsadą $\mathrm{Na}$ dnie. I tak jak pierwszy jest sporem Klaudiusza i Hamleta, tak drugi prowadzą Satin i Baron, grani przez Gavenonisa i Meškauskasa. Rozgrywając je w tym samym gronie, Koršunovas wskazuje na ich podobieństwa, czyniąc z nich niemal dyptyk.

Jak pisał Drewniak, nazywając spektakl „modlitwą, za tych, którym się nie udało” zespół żegnał w ten sposób Sauliusa Mykolaitisa, aktora zmarłego tragicznie w 2006 roku, a potem także ulubioną scenografkę OKT Jūratė Paulèkaite, która rok po premierze dołączyła do grona przedwcześnie odeszłych kolegów (Drewniak 2013b). Nie przekreśla to jednak innego wymiaru przedstawienia: alkohol zagłusza metafizyczną pustkę w życiu bohaterów, przynosząc chwilowe odprężenie, ale w efekcie zabija pamięć i zdolność do uczuć wyższych, skazując ich prędzej czy później na przegraną. Mimo wszystkich zmian na lepsze i cywilizacyjnych udogodnień, okazuje się stałym komponentem europejskiego pejzażu.

\section{Dysydent na wyspie}

Swoją pierwszą Burzę Koršunovas wyreżyserował w Reykjaviku (2010). W rozmowie z Barbarą Świąder, po polskiej premierze Mirandy mówił:

W zeszłym roku robiliśmy Burzę w Islandii. Była zupełnie inną realizacją - właśnie taką baśniową feerią. Na pozór spektakl był piękną i czytelną metaforą - wyspa była w nim wspaniałym teatrem barokowym, a Prospero - reżyserem. Coś mnie jednak tknęło, poczułem, że coś się nie zgadza, jest nieprawdziwe. Że w tym tekście jest dużo więcej niż to, co pokazujemy. Trzeba tylko poszukać głębiej. Zrozumiałem, że w Burzy jest coś ważniejszego, co dotyka mnie osobiście, i to bardzo głęboko, bo przychodzi z mojego własnego doświadczenia (Drewniak 2013a).

Koršunovas prowadził te poszukiwania na Węgrzech, ale z litewskim zespołem, w połowie lipca 2011 roku, dając tam prapremierę Mirandy, którą dwa tygodnie potem prezentował w Gdańsku, na Festiwalu Szekspirowskim ${ }^{1}$. Scenografia Dainiusa Liškevičiusa przedstawiała pokój - do którego prowadziły centralnie umieszczone białe, oszklone drzwi - z upchaną książkami meblościanką, telewizorem i radiem na nóżkach, z palmą, fotelami, kilkoma lampami, z rozstawionymi na stoliku szachami. Pomieszczenie rodem z poprzedniego ustroju. Większość widowni dobrze pamiętała te realia, choć przez ostatnie dwadzieścia lat rzadko były obecne na scenach, stanowiąc niemałe zaskoczenie. $\mathrm{W}$ tym

\footnotetext{
1 Festiwal Szekspirowski był koproducentem spektaklu Miranda.
} 
królestwie rządził dojrzały mężczyzna w okularach (Povilas Budrys), opiekujący się niepełnosprawną córką (Airida Gintautaitė). Karmił ją, masował i gimnastykował jej spastyczne ciało, a ona wyciągała ręce niczym baletnica, której figurka stała na jednej z półek. Chciała, by ojciec czytał jej Burzę Szekspira. W ten sposób byliśmy wprowadzani w akcję dramatu.

Mężczyzna próbował czasami kontaktować się ze światem zewnętrznym: włączał radio, ale zagłuszanie uniemożliwiało odsłuch, przez ekran rozstrojonego telewizora przebiegały zakłócenia, telefon nie odpowiadał. Prospero najwyraźniej popadł w niełaskę. Na swojej wyspie, którą stanowiło jego mieszkanie, panował za to niepodzielnie. Jednak zdana na niego Miranda we śnie zamieniała się w Ariela i żądała wolności. Odzyskiwała władzę nad ciałem, a to dawało jej siłę i zaczynała kłócić się z ojcem. On z kolei w okamgnieniu przemieniał się w młodego Ferdynanda, łatwo zdobywającego drogę do jej serca. Nagle stawał się powabnym, szczupłym młodzieńcem w rozpiętej koszuli, rozprawiającym o miłości. Ale już za chwilę wcielał się w prymitywnego, upijającego się i obscenicznego Kalibana, tracącego wszystkie hamulce i gwałcącego dziewczynę. Aktorzy zmieniali kostiumy i osobowości. Odgrywali to wszystko przed sobą, bo pokój był ich całym światem, a Burza jedynym scenariuszem. Bo nie było nikogo innego. W sennych marzeniach córka przestawała być zależna od ojca, a on nie był już zmuszony do jej piastowania. Pokonywali własne ograniczenia.

Trudno oddzielić fantazmaty od faktów, bo choć scenografia była realistyczna, to muzyka Atanasa Jasenki i niepokojące, pulsujące światło zacierały ostrość obrazu. Spektakl był pełen ekspresji z racji ciągłych zmian tożsamości bohaterów, dramatyzmu samej akcji i talentu wykonawców. Co było rzeczywistością, a co wyobrażeniem - pozostawało niejasne. Na scenie toczyła się psychodrama, wyrażana słowami Szekspira, która miała polityczne podłoże, jak w Burzy. Koršunovas sięgnął rzeczywiście głęboko. Pokazał komunistyczną opresję poprzez kaleką sytuację rodzinną: ludzi odciętych od świata, zdanych na siebie do tego stopnia, że zaczynających się krzywdzić. Głęboki regres, jaki autorytarna władza powoduje w życiu osobistym podwładnych. Portret sytuacji często występującej w poprzednim ustroju, a przy tym nieheroizującej ofiar. „Znałem takie wyspy i takich Prosperów - mówił po gdańskiej premierze reżyser. - Znałem takich intelektualistów, pisarzy i ich maleńkie mieszkania wypełnione książkami, cele, w których pozostawali sami ze swoimi lekturami, myślami. Ich jedynym ratunkiem były książki. Pisali do szuflad. W tych swoich klitkach wychowywali swoje Mirandy...” (Koršunovas 2011). O tych samotnikach mówił z pełnym szacunkiem, ale na scenie pokazywał szaleństwo Prospera uwięzionego we własnym domu.

Co jakiś czas w spektaklu powracał fragment Jeziora łabędziego Czajkowskiego, pojawiający się też, w postaci relacji z wykonania baletu, na ekranie telewizora. Mówił Koršunovas w Gdańsku:

Dla mieszkańców byłego ZSRR to bardzo dobrze znany znak, złowrogi znak. Objawił się nam po raz pierwszy, kiedy zmarł pierwszy sekretarz, Leonid Breżniew. Nie podawano wtedy żadnych informacji, a w telewizji przez dwa dni non stop pokazywano Jezioro łabędzie. Potem jeszcze kilka razy były takie dni z Jeziorem tabędzim. Dlatego w 1991 roku, kiedy w Moskwie odbył się pucz Janajewa i ludzie zobaczyli na ekranach Jezioro tabędzie, od razu wiedzieli, że trzeba wychodzić na ulice (Koršunovas 2011).

Spektakl operujący realistyczną scenografią okazał się wielką metaforą. Równie dobrze nieistniejącą postacią mogła być w nim Miranda. Była przecież tworem Prospera (jego duszą, jak sugerował reżyser w wywiadzie). Potwierdzałby to finał przedstawienia, w którym 
powracał motyw z Czajkowskiego. Bohater odurzony alkoholem zasypiał przy włączonym, ale zepsutym telewizorze, otwierały się drzwi i Gintautaitè w kostiumie Białego Łabędzia tańczyła do rozlegającej się głośno muzyki. Słyszeliśmy też dźwięk telefonu, niosącego być może zaproszenie do nowej rzeczywistości. Ale nie było nikogo, by go odebrać. Może więc rzeczywiście wszystko, co oglądaliśmy na scenie, stanowiło wytwór umysłu samotnego intelektualisty, tuż przed finałem popijającego z butelki i rozgrywającego z samym sobą partię szachów.

Jak pisał Drewniak: „wierni widzowie teatru Koršunovasa pamiętają, że w identycznym stroju baletnicy objawiała się bohaterowi Staruchy jego Śmierć” (Drewniak 2013a). Wiemy też, że śmierć bohaterki baletu wieńczyła Jezioro łabędzie. Bohaterki marzącej, tak jak spastyczna Miranda, o wyzwoleniu z niechcianego, łabędziego ciała. Zatem i ona sama mogła być jej znakiem. Poniekąd zresztą była: emisja baletu w radzieckiej telewizji oznaczała przecież śmierć na szczytach władzy, bo tylko wtedy (niczym w kronikach królewskich Szekspira) zachodzily zmiany.

Miranda, jak większość przedstawień Koršunovasa, opowiadała o twórczości i samotności artysty, tym razem dysydenta, ale operowała na kilku poziomach. W swojej warstwie najprostszej była to historia ojca i córki, zdanych na siebie, karmiących wyobraźnię Burzq Szekspira i wcielających się w jej bohaterów. Być może wcielenia te były tylko grą, jaką podejmowali wobec siebie; pytanie, jak bardzo zbliżały się do rzeczywistości. Wizerunek dysydenta, któremu przydarzały się takie przygody jak Kalibanowi, byłby wówczas dość gorzki. Pokazywałby „zarażenie złem” ofiar systemu: wykoślawione relacje osobiste, kalekie związki, jakie powoduje niemożność zawodowej realizacji czy odcięcie od świata: brak wymiany myśli, doświadczeń i emocji. I obecny w tym wszystkim alkohol. Wówczas Burza, ta „tragedia straconych złudzeń” (Kott 1997), jak nazywał ją Kott, brzmiałaby rzeczywiście gorzko i dwuznacznie. Ale być może wszystko, co widzieliśmy na scenie, było dziełem umysłu i wyobraźni bohaterów albo samego Prospera. Choć, jeśli taki obraz powstawał w ich (jego) fantazji - też nie najlepiej świadczył o rzeczywistości. Wielkość reżysera Mirandy polegała m.in. na tym, że tego ostatecznie nie przesądzał i nie dopowiadał.

Trzy spektakle dojrzałego już reżysera - realizacje klasycznych dramatów - podejmują wątki bardzo osobiste dla Koršunovasa i zespołu OKT, ale można je także interpretować szerzej. Hamlet zwraca uwagę na bezsilność bohaterów wobec mechanizmów historii, które wprawione w ruch przemielą ich życie, ulegając tylko korekcie za sprawą protagonisty, ale także na bezsilność reżysera i aktorów wobec teatru, któremu poświęcają wszystkie wysiłki i życie prywatne, a ich ofiara może tylko nieznacznie skorygować rozwój sztuki i jej wpływ na współczesnych. $\mathrm{Na}$ dnie - to biesiada z publicznością w manierze rosyjskiej, rozpięta między libacją i ostatnią wieczerzą, pokazująca metafizyczną pustkę nadal leczoną alkoholem, sto lat po powstaniu dramatu Gorkiego, w świecie cywilizacyjnych osiągnięć i rozwiniętych technologii. Miranda jest spektaklem o bezimiennych męczennikach poprzedniego ustroju, wpływie władzy autorytarnej na życie prywatne, rzeczywistej cenie, jaką płaci się za wygnanie i odosobnienie. Powstał on w procesie szukania tego, co ukryte, nieprzepracowane. Co samo się odsłania, kiedy w tej części Europy myśli się o nadużyciach władzy i jej złym wpływie na ludzi. 
Oprócz sportretowanej w tych przedstawieniach, dramatycznej sytuacji artysty, który spala się, by sprostać swemu talentowi (a inni bohaterzy, by sprostać własnemu losowi) jest w nich także poszukiwanie metafizyki. W Hamlecie wahanie bohatera cofającego się przed zabójstwem Klaudiusza powoduje w efekcie śmierć protagonisty. Jego los jest tragiczny, ale przerywa działanie Wielkiego Mechanizmu. Ma więc sens, patrząc z perspektywy następnych pokoleń. Bohaterzy jednak nie docierają doń i do płynącej stąd nadziei, jakby przestali odczytywać kod własnej kultury, zapomnieli, na jakich fundamentach została wzniesiona. Nie wiedzą, jak znaleźć drogę wyjścia z egzystencjalnej rozpaczy, zmagają się z losem bez wiary w wyższy sens. W Na dnie był ktoś, kto ją budzil, ale odszedł i pozostało po nim puste miejsce. W Mirandzie Prospero jest więźniem totalitarnego systemu, który albo odgrywa poszczególne sekwencje Burzy, usiłując poradzić sobie z własną traumą, albo, co gorsza, zaprowadza go także we własnym domu, bo silnie emanujące zło udziela się wszystkim, także prześladowanym. Nie wiadomo nawet, czy sam Hamlet rozumie sens własnego losu. Ale reżyser tych przedstawień z pewnością rozumie ludzką potrzebę sensu.

Zwraca uwagę osobność Koršunovasa nie tylko w litewskim teatrze, ale i wśród utalentowanych rówieśników wprowadzających na europejskie sceny nowy język. Ten, który w początkach zawodowej drogi wydawał się buntownikiem bez powodu, okazał się z latami odporny także na mody i ideologie nowego świata, czego dobitnym wyrazem było Wygnanie (2011) według sztuki Mariusa Ivaškevičiusa, prezentowane w Warszawie podczas Spotkań Teatrów Narodowych. Reżyserem świadomie nawiązującym do dramatycznej historii, ale i do rudymentów europejskiej cywilizacji.

\section{Bibliografia}

Koršunovas, Oskaras 2011. „Mój adres, mój notes, mój sposób na życie. Z Oskarasem Koršunovasem rozmawia Barbara Świąder". Teatr 10.

Drewniak, Łukasz 2013a. „Mus. Opowieść o Oskarasie Koršunovasie i jego generacji”. W: Spotkanie Teatrów Narodowych Warszawa - książka festiwalowa. Warszawa: Teatr Narodowy, 3-19 czerwca $2013 \mathrm{r}$.

- 2013b. „Mus”. Teatr 10.

Kott, Jan 1997. Szekspir wspótczesny. Kraków: Wydawnictwo Literackie.

- 1999. Szekspir wspótczesny 2. Kraków: Wydawnictwo Literackie.

Matuszak, Marzena (reż.) 2008. Rozmowy istotne. [Film]. Współ. Maciej Chmiel. TVP Kultura.

Zawrzykraj, Agata 2000. „Shakespeare współczesny: dramat ambiwalencji seksualnej”. Dialog 11.

Zembrzuski. „Hamletas”. jacekkrzysztof.blog.onet.pl. 